\title{
Comparison of Metal-Ammine Compounds Binding to DNA and Heparin. Glycans as Ligands in Bioinorganic Chemistry
}

\author{
Samantha J. Katner, ${ }^{\dagger}$ Wyatt E. Johnson, ${ }^{\dagger}$ Erica J. Peterson, ${ }^{\dagger}$ Phillip Page, ${ }^{\dagger}$ and Nicholas P. Farrell $*^{\dagger}{ }^{\dagger}$ \\ ${ }^{\dagger}$ Department of Chemistry and Massey Cancer Center, Virginia Commonwealth University (VCU), Richmond, Virginia 23284, \\ United States \\ ${ }^{\ddagger}$ Reichert Technologies, Depew, New York 14043, United States
}

\section{Supporting Information}

ABSTRACT: We present spectroscopic and biophysical approaches to examine the affinity of metal-ammine coordination complexes for heparin as a model for heparan sulfate (HS). Similar to nucleic acids, the highly anionic nature of heparin means it is associated in vivo with physiologically relevant cations, and this work extends their bioinorganic chemistry to substitution-inert metal-ammine compounds ( $M)$. Both indirect and direct assays were developed. $\mathrm{M}$ compounds are competitive inhibitors of methylene blue (MB)-heparin binding, and the change in the absorbance of the dye in the presence or absence of heparin can be used as an indirect reporter of $\mathrm{M}$-heparin affinity. A second indirect assay uses the change in fluorescence of TAMRA- $\mathrm{R}_{9}$, a nonaarginine linked to a fluorescent TAMRA moiety, as a reporter for $\mathrm{M}$-heparin binding. Direct assays are surface plasmon resonance (SPR) and isothermal titration calorimetry (ITC). The $K_{\mathrm{d}}$ values for TriplatinNC-heparin varied to some extent depending on the technique from $33.1 \pm 2 \mathrm{nM}$ (ITC) to $66.4 \pm 1.3 \mathrm{nM}$ (MB absorbance assay) and $340 \pm 30 \mathrm{nM}$ (SPR). The differences are explained by the nature of the technique and the use of heparin of differing molecular weight. Indirect probes using the displacement of ethidium bromide from DNA or, separately, fluorescently labeled oligonucleotide (DNA-Fl) can measure the relative affinities of heparin and DNA for M compounds. These assays showed essentially equivalent affinity of TriplatinNC for heparin and DNA. The generality of these methods was confirmed with a series of mononuclear cobalt, ruthenium, and platinum compounds with significantly lower affinity because of their smaller overall positive charge but in the order $\left[\mathrm{Co}\left(\mathrm{NH}_{3}\right)_{6}\right]^{3+}>\left[\mathrm{Ru}\left(\mathrm{NH}_{3}\right)_{6}\right]^{3+}>\left[\mathrm{Pt}\left(\mathrm{NH}_{3}\right)_{4}\right]^{2+}$. The results on heparin can be extrapolated to glycosoaminoglycans such as HS, emphasizing the relevance of glycan interactions in understanding the biological properties of coordination compounds and the utility of the metalloglycomics concept for extending bioinorganic chemistry to this class of important biomolecules.

\section{INTRODUCTION}

Glycosaminoglycans (GAGs) such as heparan sulfate (HS) are linear polysaccharides composed of repeating disaccharide units of alternating uronic acid and hexosamine residues. When conjugated with proteins, heparan sulfate proteoglycans (HSPGs) are found on the cell surface and extracellular matrix with critical functions in cellular adhesion and migration. ${ }^{1,2} \mathrm{HS}$ is structurally related to heparin, a free GAG chain produced by mast cells that may be deployed as an immune defense mechanism. ${ }^{3,4}$ Heparin usually remains highly sulfated, whereas HS displays varying degrees of sulfation. ${ }^{1,2}$ HS has a multitude of protein partners, mediated through hydrogen-bonding and electrostatic interactions between sulfated regions of the polysaccharide and the basic amino acids of the protein..$^{5-7}$ Specifically, HSPGs interact with pro-angiogenic growth factors such as fibroblast growth factor (FGF) to induce dimerization for subsequent activation of its receptor. ${ }^{5,8}$ FGF-2 directly stimulates tumor and endothelial cell proliferation, migration, and survival. ${ }^{6}$ In addition to protein interactions, heparin and HSPGs are cleaved at glycosidic bonds by bacterial and mammalian enzymes (heparinase and heparanase, respectively). This HS cleavage leads to degradation of the extracellular matrix and release of growth factors for tumor angiogenesis. ${ }^{9}$ Heparanase has a high abundance in many tumors, correlating with increased metastatic potential and poor clinical prognosis. $^{10-12}$ HSPGs and their associated proteins and enzymes are thus attractive drug targets because of their promotion of tumor progression at multiple levels: proliferation, invasion, angiogenesis, and metastasis. ${ }^{3-7}$

The highly anionic nature of heparin and HS means they are associated in vivo with physiologically relevant cations, similar to nucleic acids. ${ }^{13-15}$ Cation association affects the biomolecule conformation and, in some cases, facilitates heparin-protein interactions such as $\mathrm{Ca}^{2+}$-dependent heparin-annexin $\mathrm{A} 2$ binding. ${ }^{16}$ More broadly, $\mathrm{Cu}^{2+}$ promotes angiogenesis, although the detailed mechanism is not defined. ${ }^{17,18}$ Growth factors are also copper-dependent, with a slightly higher affinity for FGF-1

Received: December 6, 2017 
compared to FGF-2. ${ }^{19,20}$ Aquated $\mathrm{Ca}^{2+}, \mathrm{Mg}^{2+}, \mathrm{Fe}^{3+}$, and $\mathrm{Zn}^{2+}$ ions, at higher than physiological concentrations, reduce FGF-1 interactions with HS-heparin. ${ }^{13}$ For heparin and HS, there are no strong donor atoms such as the heterocycle nitrogen atoms of purines and pyrimidines or even sulfur and nitrogen donors of amino acids such as cysteine and histidine available for binding to metal centers, suggesting that harder acids may preferentially bind and/or the oligosaccharides can enter into "noncovalent" electrostatic or hydrogen-bonding interactions (Figure 1). In recent papers, we have suggested that metalloglycomics, defined as the study of metal ionoligosaccharide interactions, can be expanded beyond the study of physiologically relevant aquated metal cations to use defined coordination compounds. ${ }^{21-24}$

Using coordination compounds, alteration of the oxidation state, coordination number, and geometry and substitution lability of ligands allows for the study of a wide variety of structural types to examine the structure and function of sulfated oligosaccharides, extending bioinorganic chemistry to this third major class of biomolecules after DNA/RNA and proteins. Specifically, HSPGs act as receptors for cellular accumulation of the highly cationic polynuclear platinum complexes (PPCs). ${ }^{21}$ Molecular recognition of a compound such as TriplatinNC (Figure 2) is effected through electrostatic and hydrogen-bonding interactions with the sulfate groups on the HS chains, analogous to the phosphate clamp formed by the same complex on DNA (Figure 1a,b). ${ }^{22-24}$ This highaffinity sulfate binding, or metalloshielding, has functional consequences including stabilization of the sulfate moieties, in a defined sequence octasaccharide, from dissociation in the gas phase. $^{23}$ In biophysical studies, PPC metalloshielding inhibits oligosaccharide backbone cleavage by both bacterial (heparinase I) and mammalian (heparanase) enzymes. ${ }^{22,23}$ Growth factor binding to HS is inhibited in the presence of TriplatinNC with consequent effects on downstream kinase signaling. ${ }^{22}$ Overall, these interactions lead to the inhibition of cellular angiogenesis and eventually the inhibition of in vivo metastasis (Figure 1c). ${ }^{25,26}$

The molecular-level explanation of these events requires a detailed understanding of PPC-glycan interactions. The identity and conformation of the sugar and the number and positions of sulfation make GAGs highly complex systems, with significantly more variability than DNA, also with respect to non-bond-forming interactions. As polyelectrolytes, heparin and DNA have strong electrostatic interactions that, for heparin and other glycans such as HS, are influenced by the positions and amount of sulfation. Heparin is often used as a model for a highly sulfated HS and is considered to have the highest negative charge density of any biomolecule at an average of 2.7 sulfate groups per disaccharide. ${ }^{3}$ This paper evaluates spectroscopic and biophysical approaches to examine metal ion-heparin interactions, especially in the case of substitutioninert PPCs such as TriplatinNC. The fundamental unit of TriplatinNC is the mononuclear tetraam(m)ineplatinum(II), and charge-related effects may be examined by a comparison of mononuclear and poly(tri)nuclear species. The generality of these approaches is exemplified by extension to other mononuclear metal-ammine complexes based on cobalt and ruthenium. The fluorescent properties of $\left[\mathrm{Ru}(\mathrm{bpy})_{3}\right]^{2+}$ and its analogues have been used as analytical probes to examine the heparin concentration and even content in cells. ${ }^{27-29}$ In this paper, we therefore compared the relative reactivities of the chosen set of compounds toward both biomolecules (DNA and
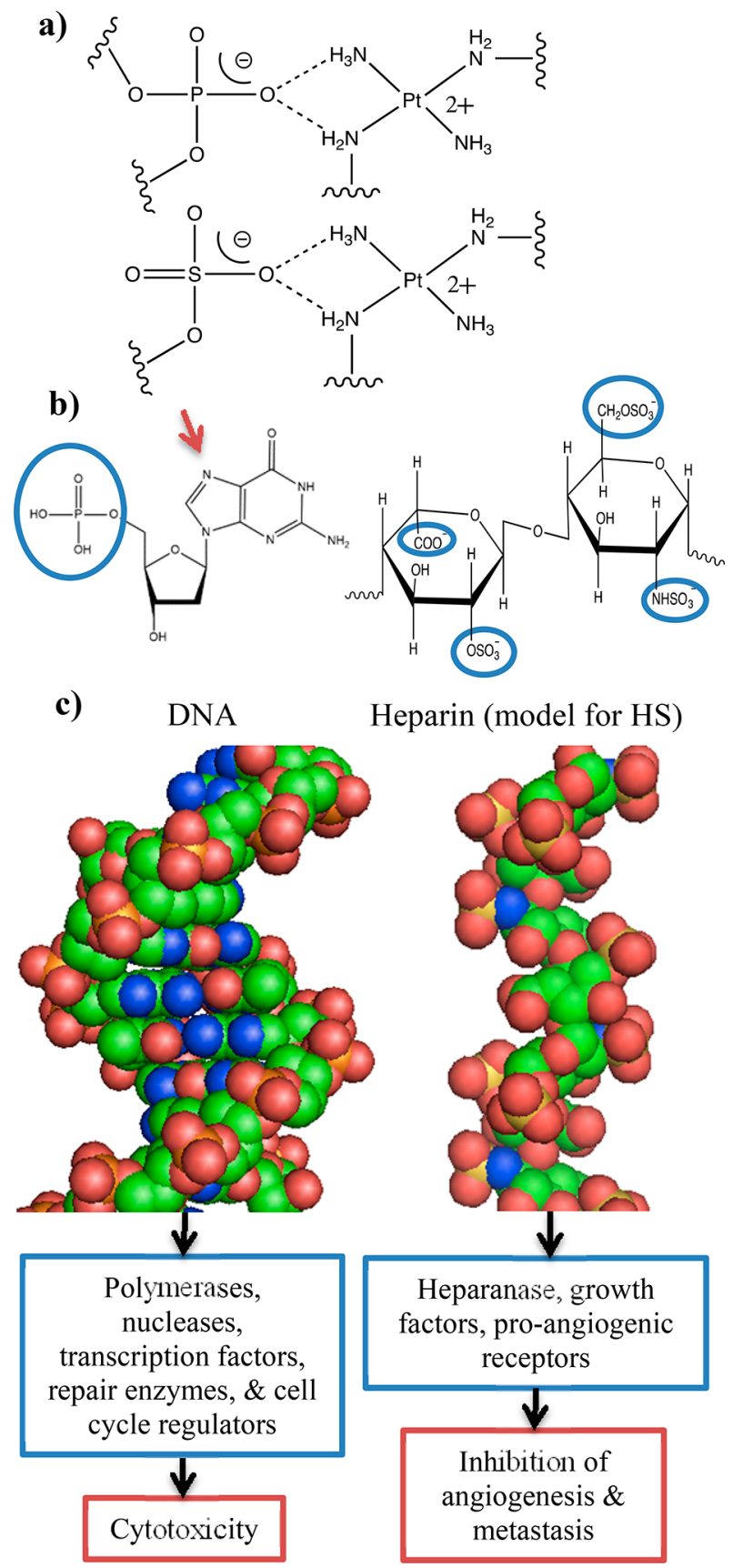

Figure 1. (a) Proposed structural analogy of the phosphate clamp to DNA (top) and the sulfate clamp to heparin or a sulfated glycan (bottom) formed by PPCs. (b) Blue circles on the repeating $\operatorname{IdoA}(2 \mathrm{~S})-\mathrm{GlcNS}(6 \mathrm{~S})$ dimer in heparin (right) and 2 -deoxyguanosine $5^{\prime}$-monophosphate (left) in DNA indicating possible electrostatic interaction sites, and a red arrow showing the favored GuanineN7 site of covalent binding. (c) DNA (PDB: 309D) and heparin (PDB: 1HPN) having high negative charge densities, and glycans such as HS having different protein recognition and signaling pathways (blue boxes). Inhibition of these pathways results in different biological consequences (red boxes).

heparin) and in a novel competition assay showed that heparin is a competitor for metal complex-DNA binding. The overall results emphasize the relevance of glycan interactions for understanding the biological properties of coordination compounds and the potential for extending bioinorganic chemistry to this important class of biomolecules. 


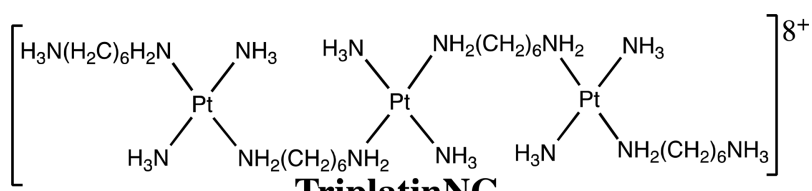

TriplatinNC

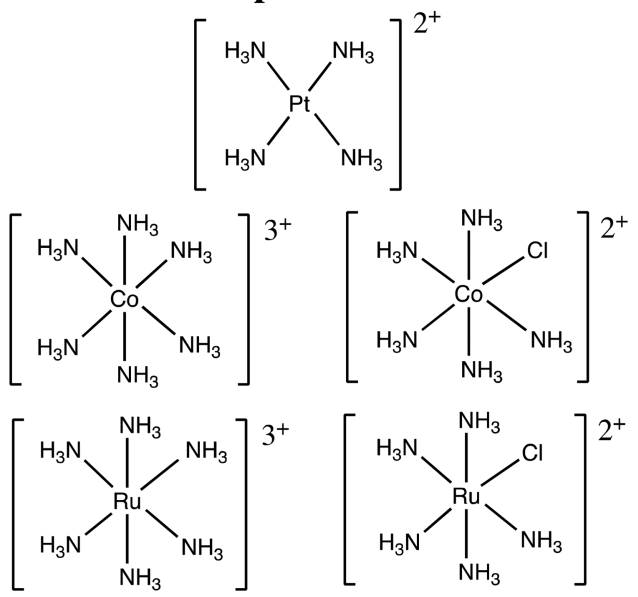

Figure 2. Structures of TriplatinNC and metal-ammine compounds used in this study. Counterions are omitted for clarity.

\section{RESULTS AND DISCUSSION}

We first examined the binding of TriplatinNC and subsequently extended the studies to the cobalt and ruthenium systems (Figure 2).

The Case of TriplatinNC. Indirect Assays: Methylene Blue (MB) Competition (Absorbance). The cationic dye MB has been used to quantify heparin content and examine heparin binding interactions. ${ }^{30-32} \mathrm{MB}$ interaction with heparin causes a concentration-dependent reduction in its absorbance. With increasing heparin concentration, the $\mathrm{MB}$ absorbance at 664 and $614 \mathrm{~nm}$ decreases while that at $570 \mathrm{~nm}$ increases, allowing for calculation of the affinity constants (Figure 3a). ${ }^{30}$ The Scatchard model (eq S1a) gave a dissociation constant $\left(K_{\mathrm{d}}\right)$ value for the $\mathrm{MB}$-heparin interaction of $351 \mathrm{nM}$, comparable to a previously reported value of $578 \mathrm{nM}$ (reported originally as the association constant) measured between $\mathrm{MB}$ and chondroitin sulfate (another type of GAG). ${ }^{33}$

In the presence of heparin bound to varying concentrations of TriplatinNC, the absorbance of added MB dye (at a constant concentration) varies depending on how much TriplatinNC is released due to competitive dye binding: [Hep][TriplatinNC] $+\mathrm{MB} \rightleftharpoons[\mathrm{Hep}][\mathrm{MB}]+$ TriplatinNC (Figure $3 \mathrm{~b}$ ). The disruption of TriplatinNC binding by MB can be reported as $\mathrm{IC}_{50}$, the concentration of the complex necessary to give $50 \%$ of free dye, as monitored by MB absorbance (Table 1). By using $\mathrm{MB}$ as a reporter for competitive inhibition in a three-species system, the $K_{\mathrm{d}}$ value between TriplatinNC and heparin was calculated to be $66.4 \pm 1.3 \mathrm{nM}$ (Table 1 and eq S1b).

We also evaluated the competitive binding interactions between TriplatinNC and $\mathrm{MB}$ in the presence of other physiologically relevant cations. The presence of physiological concentrations of other cations affects the absorbance of the dye in the $\mathrm{MB}$-heparin interaction. ${ }^{34}$ The change in absorbance varies depending on the degree of cation release due to competitive dye binding, and this release is based on the concentration, charge, and ionic radius of the cations. ${ }^{34}$ High concentrations of $\mathrm{Na}^{+}$showed the greatest effect on $\mathrm{MB}$ binding, followed by $\mathrm{Ca}^{2+}>\mathrm{Mg}^{2+}>\mathrm{K}^{+}$(Figures $3 \mathrm{c}$ and $\mathrm{S} 1$ ).
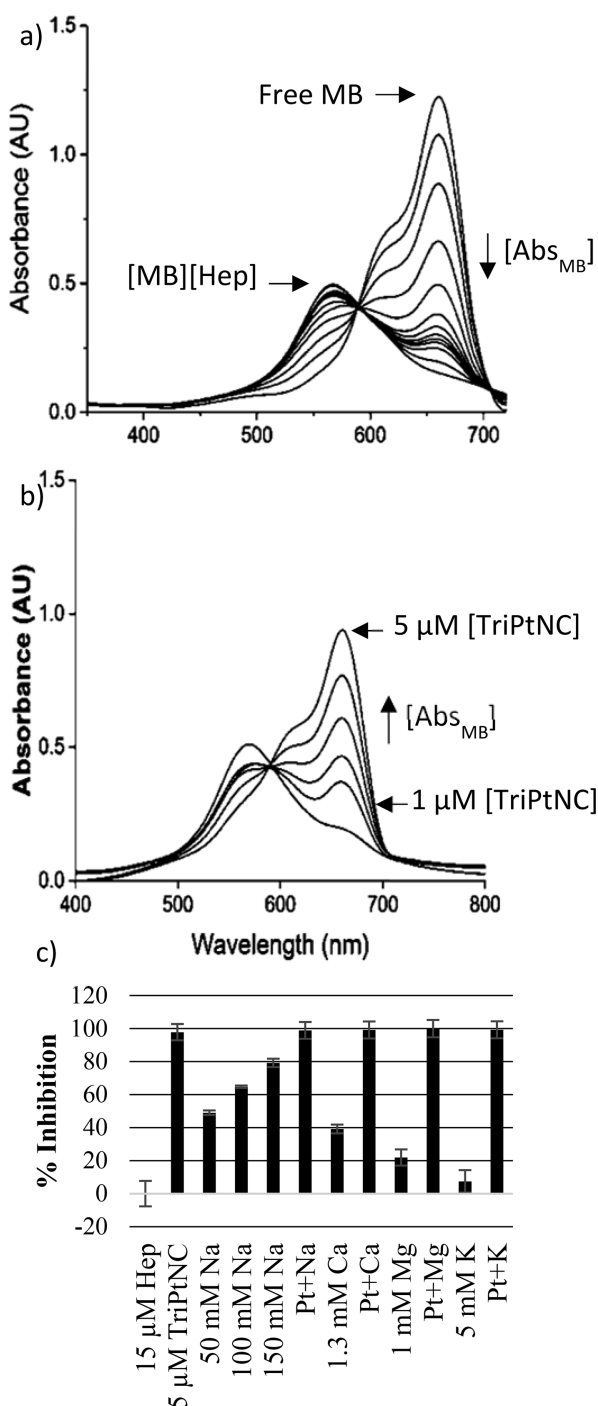

Figure 3. $\mathrm{MB}$ competition assay for assessment of heparin MW $\sim 18000$ binding. (a) The absorbance of a constant concentration of free $\mathrm{MB}\left(\left[\mathrm{Abs}_{\mathrm{MB}}\right]\right)$ at $664 \mathrm{~nm}$ decreases with increasing heparin concentration (from top to bottom with $0-15 \mu \mathrm{M}$ ) with a concomitant increase in the absorbance of $[\mathrm{MB}][\mathrm{Hep}]$ at $560 \mathrm{~nm}$. (b) At a constant concentration of $15 \mu \mathrm{M}$ heparin in the presence of varying concentrations of TriplatinNC (from bottom to top with $0-5$ $\mu \mathrm{M}), \mathrm{MB}$ binding is inhibited, reflected in the change of $\left[\mathrm{Abs}_{\mathrm{MB}}\right]$. (c) The percent inhibition of $\mathrm{MB}(18.6 \mu \mathrm{M})$ binding to heparin $(15 \mu \mathrm{M})$ by TriplatinNC $(5 \mu \mathrm{M})$ in the presence of physiologically relevant concentrations of cations is observed at $664 \mathrm{~nm}$. Charges are omitted for clarity.

With the addition of TriplatinNC (at a constant concentration), $\mathrm{MB}$ binding is further inhibited with no observed difference from the TriplatinNC-heparin binding in the presence of other cations, although the increase in inhibition is consequently smaller in the case of the highest concentrations of $\mathrm{Na}^{+}$at $150 \mathrm{mM}$. There is a difference between the $\mathrm{Na}^{+}$effects on DNA, where concentrations above $600 \mathrm{mM}$ were needed to completely restore condensed DNA to the relaxed form in the presence of TriplatinNC, which is a very effective DNA condensing agent. ${ }^{35,36}$ We note that the SPR data to be discussed below were obtained in the presence of $150 \mathrm{mM} \mathrm{NaCl}$, confirming that TriplatinNC is capable of binding to heparin at physiologically relevant concentrations of small cations. 
Table 1. $\mathrm{IC}_{50}$ and $K_{\mathrm{d}}$ Values of TriplatinNC and MetalAmmine Compounds in Competitive Inhibition Assays Using MB or TAMRA-R,

\begin{tabular}{lcccc} 
& \multicolumn{2}{c}{$\mathrm{MB}$} & & TAMRA-R \\
\cline { 2 - 3 } \cline { 5 - 5 } metal complex & $\mathrm{IC}_{50}(\mu \mathrm{M})^{a}$ & $K_{\mathrm{d}(\text { app })}{ }^{b}$ & & $\mathrm{IC}_{50}(\mu \mathrm{M})^{a}$ \\
TriplatinNC & $3.1 \pm 0.1$ & $66.4 \pm 1.3 \mathrm{nM}$ & & $62.9 \pm 1.1$ \\
{$\left[\mathrm{Co}\left(\mathrm{NH}_{3}\right)_{6}\right]^{3+}$} & $16.9 \pm 0.4$ & $367 \pm 9.0 \mathrm{nM}$ & & $77.8 \pm 3.2$ \\
{$\left[\mathrm{Ru}\left(\mathrm{NH}_{3}\right)_{6}\right]^{3+}$} & $46.4 \pm 0.7$ & $1.0 \pm 0.1 \mu \mathrm{M}$ & & $\mathrm{N} / \mathrm{A}$ \\
{$\left[\mathrm{Pt}\left(\mathrm{NH}_{3}\right)_{4}\right]^{2+}$} & $265 \pm 6$ & $5.8 \pm 0.1 \mu \mathrm{M}$ & & $255 \pm 12$ \\
{$\left[\mathrm{CoCl}\left(\mathrm{NH}_{3}\right)_{5}\right]^{2+}$} & $392 \pm 1$ & $8.5 \pm 0.1 \mu \mathrm{M}$ & & $539 \pm 23$ \\
{$\left[\mathrm{RuCl}\left(\mathrm{NH}_{3}\right)_{5}\right]^{2+}$} & $553 \pm 14$ & $12.0 \pm 0.3 \mu \mathrm{M}$ & & $832 \pm 28$
\end{tabular}

${ }^{a_{T}}$ The $\mathrm{IC}_{50}$ value was determined as the concentration of complex required for half-maximal binding of the dye $(18.6 \mu \mathrm{M}$ or $100 \mathrm{nM})$ to heparin MW $\sim 18000(15$ or $625 \mu \mathrm{M})$ for MB or TAMRA- $\mathrm{R}_{9}$ binding assays, respectively. ${ }^{b}$ Dissociation constants were calculated from the $\mathrm{MB}$ assay for TriplatinNC and metal-ammine compound binding to heparin MW $\sim 18000$ using a competitive inhibitor model (see eq S1).

Indirect Assays: TAMRA- $R_{9}$ Competition (Fluorescence). TAMRA- $\mathrm{R}_{9}$ is a polycationic, nona-L-arginine peptide linked to a fluorescent TAMRA moiety. In this case, the fluorescence of TAMRA- $\mathrm{R}_{9}$ at $590 \mathrm{~nm}$ (emission) increases with increasing heparin concentration, and a $K_{\mathrm{d}}$ value of $109 \mathrm{nM}$ for TAMRA$\mathrm{R}_{9}$-heparin binding has been previously reported. ${ }^{37}$ In our hands, we obtained a $K_{\mathrm{d}}$ value of $405.9 \mathrm{nM}$, and the difference may be attributed to the use of a larger heparin (MW 18000) than that previously reported (Figure S2a). There is also slight variability in the $K_{d}$ values under similar conditions because heparin preparations can be very heterogeneous. ${ }^{3,37}$ We have previously used the fluorescence of TAMRA- $\mathrm{R}_{9}$ as a reporter to identify HSPGs as receptors for platinum complex cellular internalization. ${ }^{21}$ Analogous to the enhanced fluorescence of an intercalator such as ethidium bromide (EtBr) upon DNA binding, TAMRA- $\mathrm{R}_{9}$ fluorescence increases when bound to heparin. Again, in the presence of heparin bound to varying concentrations of TriplatinNC, the addition of TAMRA- $\mathrm{R}_{9}$ (at a constant concentration) results in the observation of fluorescence proportional to the amount of TAMRA- $\mathrm{R}_{9}-$ heparin binding with TriplatinNC release: [Hep][TriplatinNC] + TAMRA-R $\mathrm{R}_{9} \rightleftharpoons\left[\right.$ Hep] $\left[\right.$ TAMRA- $\left.\mathrm{R}_{9}\right]+$ TriplatinNC (Figure $S 2 b)$. The ability of TriplatinNC to compete with TAMRA- $R_{9}$ for heparin binding can be reported as the $\mathrm{IC}_{50}$ required to produce $50 \%$ fluorescence compared to control of heparin dye in the absence of the complex (Table 1).

Direct Assays: Surface Plasmon Resonance (SPR). For direct analysis, SPR was used to estimate the TriplatinNCheparin affinity. SPR is a label-free, real-time quantification of the interaction between the immobilized ligand on the sensor chip and the analyte being injected in a continuous flow over the ligand. ${ }^{38}$ When the ligand and analyte interact, the refractive index changes, and the response is reported as response units (RU). SPR has been used for determining the heparin concentration, metal-heparin binding, and metal-heparin binding effects on the growth factor and growth factor receptor recognition. ${ }^{13,39}$ A mixture of metal ions reduced the affinity of FGF-1 binding to heparin from $K_{\mathrm{d}}=22$ to $350 \mathrm{nM}^{13}$ In the study of heparin-protein interactions by SPR, heparin is preferentially immobilized onto the sensor chip rather than the protein because this more closely mimics natural biological systems, where HS is found at the cell surface as a proteoglycan and binds to target proteins. ${ }^{40,41}$ A common method for heparin immobilization is to use a biotinylated heparin and a streptavidin-coated sensor chip. ${ }^{40}$ The high charge of TriplatinNC caused significant nonspecific binding to both the dextran sensor chip surface and streptavidin. Therefore, in collaboration with Reichert Technologies, a Neutravidin-coated mixed self-assembled monolayer (mSAM) sensor chip was used to minimize the background noise and resulted in significantly lower nonspecific binding of TriplatinNC to the sensor surface, although there is still some binding to the reference, causing some distortion in the binding curves (Figure 4). At the lowest
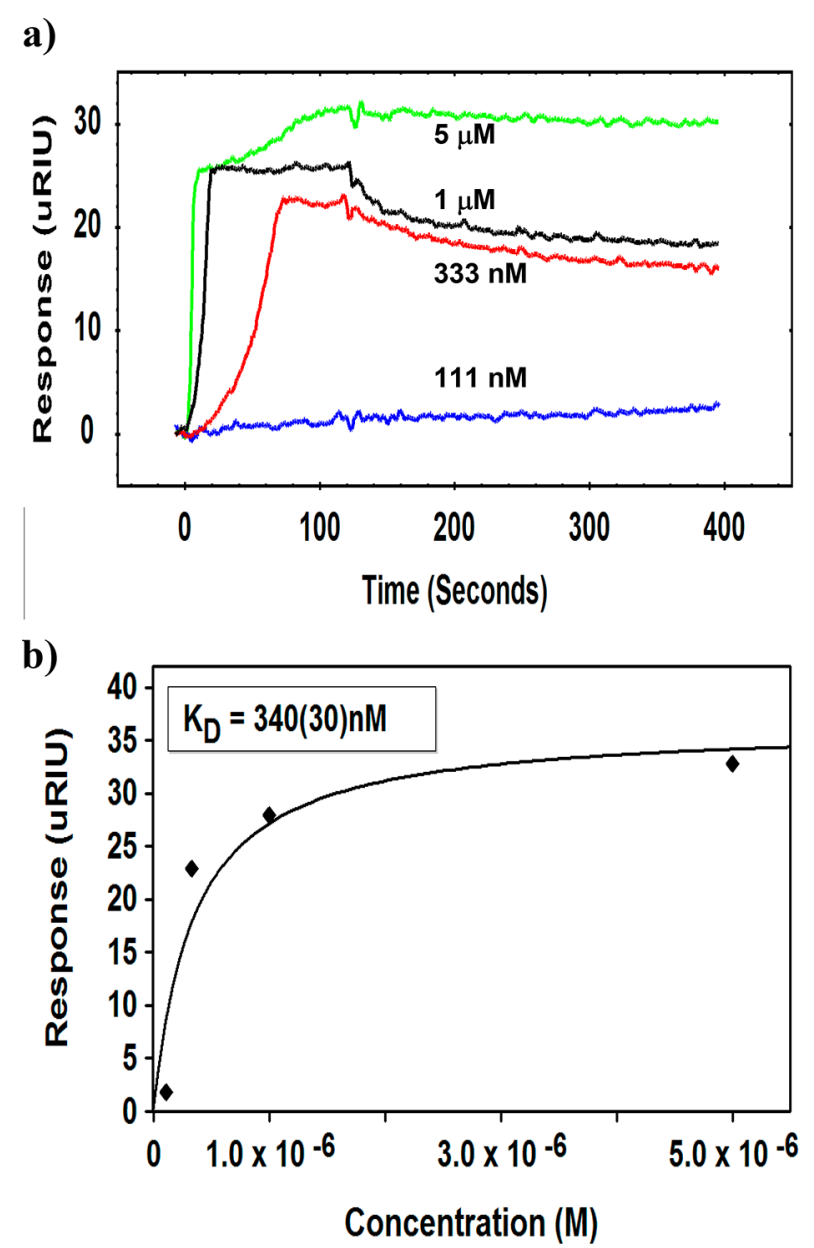

Figure 4. Determination of the TriplatinNC-heparin binding affinity by SPR using a biotinylated heparin (MW 15000) immobilized to Neutravidin on a planar mSAM chip. (a) After injection of 5, 1, 0.333, and $0.111 \mu \mathrm{M}$ of TriplatinNC, the solution was allowed to flow over the chip for $5 \mathrm{~min}$ to allow binding; a buffer was then injected, and after flowing for $5 \mathrm{~min}$, dissociation was assessed. (b) The amount of TriplatinNC bound at equilibrium was corrected for background and plotted versus input TriplatinNC concentration. Analysis by equilibrium parameters using a 1:1 binding model yielded a $K_{\mathrm{d}}$ value of $340 \pm 30 \mathrm{nM}$.

$111 \mathrm{nM}$ concentration, there was a large (repeatable) decrease in the signal, which may be due to random adsorption of the highly charged molecule in the system. An analysis of the binding curves for the interaction between heparin and TriplatinNC was generated using the TraceDrawer program. Although a global fit was not possible, a one-site model and 1:1 TriplatinNC-heparin stoichiometr, gave a $K_{\mathrm{d}}$ value of $340 \pm$ $30 \mathrm{nM}$ (Figure 4). Because the immobilized heparin had MW 15000 , it is plausible that there could be multiple binding sites, which may affect the estimated $K_{\mathrm{d}}$ values. 
Direct Assays: Isothermal Titration Calorimetry (ITC). ITC accurately determines the thermodynamic contributions of both enthalpy $(\Delta H)$ and entropy $(-T \Delta S)$ changes to the free energies of binding $(\Delta G)$. ITC measures the heat released or absorbed into the system upon the binding of two molecules and is proportional to the overall strength of binding. ${ }^{42}$ ITC has been used in heparin growth factor assays and in defining the thermodynamic parameters from these interactions. ${ }^{43,44} \mathrm{~A}$ mixture of heterogeneous heparin chains interacting with FGF-1 gave $K_{\mathrm{d}}$ values of $1.1-3 \mu \mathrm{M}$. $^{45}$ Using a smaller (MW 3000) heparin, we studied the heparin-TriplatinNC interaction by ITC. As TriplatinNC was titrated into the reaction cell containing heparin (Figure S3), the produced peaks were integrated to yield the heat released per titration. Using a onesite model for TriplatinNC-heparin gave a $K_{\mathrm{d}}$ value of $33.1 \pm 2$ $\mathrm{nM}$ (Figure S3). The enthalpy term reflects the strong electrostatic and hydrogen-bonding interactions occurring between the sulfates and ammines, while the entropic term reflects the possible release of water molecules as well as the loss of conformational mobility of the iduronic acid ring. ${ }^{42}$ This loss of conformational mobility results in a high entropy value and commonly reflects the phenomenon of entropy-enthalpy compensation. ${ }^{46}$ Overall, the interactions observed produce a spontaneous and favorable binding between TriplatinNC and heparin $(\Delta G=-10.1 \pm 0.1 \mathrm{~kJ} / \mathrm{mol})$.

Summary. Overall, the results from $M B$ and TAMRA- $\mathrm{R}_{9}$ reporter assays demonstrated strong TriplatinNC-heparin interactions, which were confirmed by SPR and ITC. MB and TAMRA- $\mathrm{R}_{9}$ dyes had similar estimated $K_{\mathrm{d}}$ values for binding to heparin itself, 351 and $405.9 \mathrm{nM}$, respectively. The TriplatinNC-heparin binding gave similar $K_{d}$ values of $66.4 \pm$ 1.3 and $33.1 \pm 2 \mathrm{nM}$ from the $\mathrm{MB}$ assay and ITC system, respectively, whereas the SPR system displayed a magnitude weaker affinity $(340 \pm 30 \mathrm{nM})$. Because the SPR system measured TriplatinNC interacting with heparin immobilized to the surface of the sensor chip, this immobilization may reduce the degrees of freedom of the heparin molecule to interact and thus affect the kinetics and affinity of the TriplatinNC-heparin interaction. ${ }^{47}$ However, the heparin immobilization more closely mimics natural biological systems where the HS chains are covalently attached to core proteins as HSPGs. There are few small molecule-heparin binding data for comparison by SPR and ITC because the majority of studies have been on protein-heparin interactions.

Comparison of the PPC-Heparin and PPC-DNA Affinities. The $K_{\mathrm{d}}$ values with heparin from the indirect reporter assays and the direct SPR and ITC techniques raise questions about the relative affinity of TriplatinNC for DNA or heparin. TriplatinNC and substitution-inert complexes in general bind with high affinity to DNA with a measured $K_{\mathrm{d}(\text { app })}$ value of $17.7 \mathrm{nM}$ (reported as $\left.K_{\mathrm{a}(\text { app) })}\right)^{48}$ Given the highly anionic nature of both biomolecules, what are the relative affinities of a molecule such as TriplatinNC for DNA or heparin? As mentioned, heparin is considered to have an average of 2.7 sulfate groups per disaccharide compared to that of two phosphate groups per base pair for DNA. We therefore developed a number of competitive binding assays to answer this question and to complement the indirect and direct HSPPC assays. Fluorescence polarization, EtBr, and circular dichroism (CD) competition assays compared the ability of heparin to compete with DNA for the binding of charged metal complexes.
DNA Competition Assay. A fluorescence polarization assay measures the tumbling motion of molecules to describe binding events. Typically, the assay incorporates a small fluorescently labeled molecule, such as a DNA oligonucleotide, and an interacting molecule of similar or higher molecular weight, such as a protein. Upon binding, the rotation of the fluorescent molecule decreases, which is measured by emission fluorescence passing through parallel and perpendicular polarized light paths. ${ }^{38}$ For our purposes, we examined whether changes in the rotation of a small fluorescently labeled DNA hairpin (DNA-Fl; 23nt; MW 7705) could be detected upon binding of the lowermolecular-weight metal complex, TriplatinNC (MW 1650).

Reproducible saturation binding curves were established with the concentration of drug required for half-maximal binding determined to be $\mathrm{EC}_{50}=1.92 \mu \mathrm{M}$ (Figure 5a and Tables 2 and S1). When the same unlabeled DNA hairpin was subsequently titrated into the reactions, a predictable shift of the curve occurred as unlabeled DNA competed with labeled DNA for binding of TriplatinNC with concomitant increases in the apparent $\mathrm{EC}_{50}$ values (Figure 5a and Table S1). The fold changes of the apparent $\mathrm{EC}_{50}$ values were 1.1, 1.9, and 11.6 with changing DNA/DNA-Fl ratios of $0.2: 1,2.11: 1$, and 21.2:1, respectively (Table S1). When heparin MW 3000 was used as the competitor ligand, the $\mathrm{EC}_{50}$ values similarly increased relative to the control DNA-Fl (Figure $5 b$ and Table 2). In comparison, the fold increases in the $\mathrm{EC}_{50}$ values were 1, 2.1, and 10.3 upon the addition of increasing concentrations (0.2$21.2 \mu \mathrm{M})$ of heparin, closely comparable to the DNA/DNA-Fl ratios used. These results therefore suggest a similar affinity for TriplatinNC between low-molecular-weight heparin and DNA substrates.

For a second competition assay, we used an adaptation of the well-known $\mathrm{EtBr}$ fluorescence assay to measure the binding affinities of metal complexes. ${ }^{22,48}$ The fluorescence from intercalator binding to DNA is quenched when the intercalator is displaced upon TriplatinNC-DNA binding. Upon the addition of increasing concentrations of heparin, TriplatinNC is sequestered and the nucleic acid now becomes available to bind the intercalator, with a resultant increase in fluorescence (Table 3). From Figure 5c, we can see that a concentration of 12.5 $\mu \mathrm{M}$ TriplatinNC reduced EtBr fluorescence to approximately $25 \%$ of the control value. A concentration of $20.5 \mu \mathrm{M}$ heparin increases fluorescence to approximately $50 \%$, while full fluorescence is restored in the $35-40 \mu \mathrm{M}$ range. The experiment allows us to define $\mathrm{EC}_{50}$ as the sequestration concentration of heparin required to restore $50 \% \mathrm{EtBr}$ binding (Table 3). This experiment again confirms the similar affinities of the two biomolecules for TriplatinNC.

$C D$ Assay. The competitive binding of heparin and DNA can also be easily envisaged by $\mathrm{CD}$ spectroscopy monitoring of the conformational changes during each event. The CD spectrum of the DNA structure influenced by its environment and changes such as TriplatinNC binding can be monitored without the need for labels. The positive CD band of DNA centered at approximately $270 \mathrm{~nm}$ is decreased in the presence of TriplatinNC (Figure S3). Upon the addition of heparin to the DNA-TriplatinNC mixture, the positive band is restored in a heparin concentration-dependent manner through sequestration of TriplatinNC and restoration of DNA to its original conformation. Neither heparin nor heparin-TriplatinNC mixtures show any CD absorbance in the $250-280 \mathrm{~nm}$ range, and thus the changes observed are direct visualizations of competitive binding. 


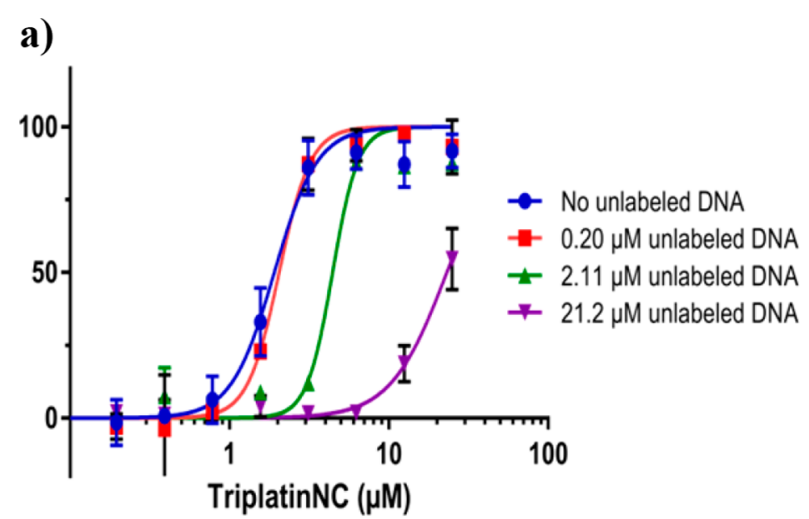

b)

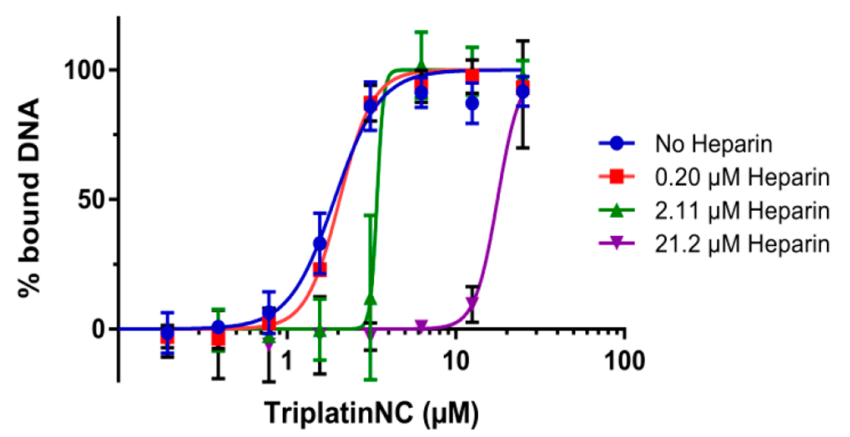

c)

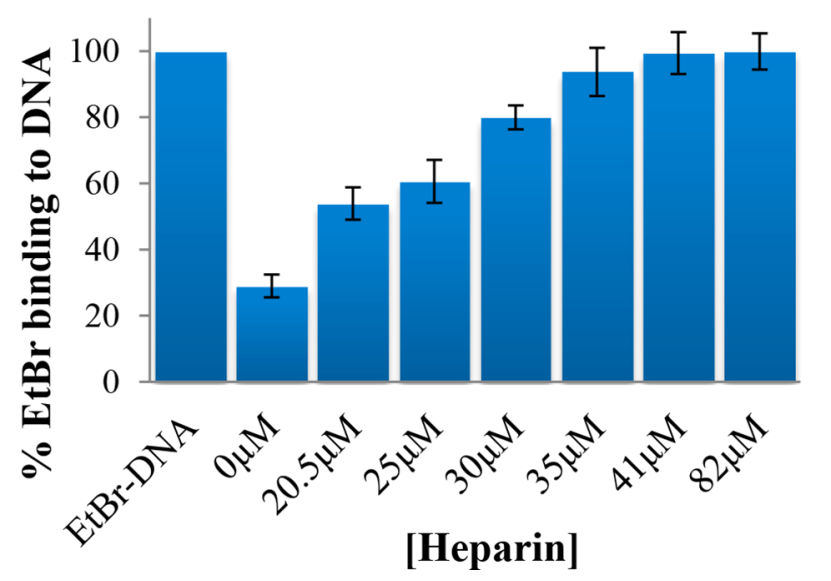

Figure 5. Heparin, a competitive inhibitor of TriplatinNC-DNA binding. (a) Unlabeled DNA $(0-21.2 \mu \mathrm{M})$ competed with fluorescently labeled DNA (23nt and MW 7705) for TriplatinNC binding. (b) Analogously, the binding of TriplatinNC to the fluorescently labeled-DNA was reduced upon the addition of heparin MW $\sim 3000(0-21.2 \mu \mathrm{M})$. (c) EtBr bound to ct-DNA was displaced upon the addition of TriplatinNC, while increasing the concentration of heparin MW 18000 sequestered TriplatinNC from DNA, allowing $\mathrm{EtBr}-\mathrm{DNA}$ binding to occur. EtBr bound to DNA was normalized to $100 \%$ with $\mathrm{EtBr}$ only as $0 \%$.

Summary. Electrostatic and hydrogen-bonding interactions with noncovalent metal complexes observed on DNA translate to heparin-HS interactions. To determine the relative affinity of TriplatinNC for heparin and/or DNA, competition assays were used with reporters for the TriplatinNC-DNA interaction. Fluorescence polarization and $\mathrm{EtBr}$ competition assays showed that TriplatinNC has a broadly similar affinity for both unlabeled heparin and DNA.
Affinity of HS Binding to Metal-Ammine Complexes. Trinuclear complexes are modular in nature, and the strong interactions of TriplatinNC with heparin led us to explore the individual contributions of the mononuclear tetraam $(\mathrm{m})$ ineplatinum(II) units and further compare charge-related effects based on cobalt and ruthenium analogues (Figure 1). While, in principle, the chloropentaammine complexes of cobalt(III) and ruthenium(III) can enter into covalent interactions through $\mathrm{Co}-\mathrm{Cl}$ or $\mathrm{Ru}-\mathrm{Cl}$ substitution, the nature of the assays developed and the kinetic inertness of substitution on the cobalt(III) and ruthenium(III) centers suggests that any trends observed across the series of compounds will be most likely due to simple differences in charge.

MB Assay. In MB assay, $\left[\mathrm{Co}\left(\mathrm{NH}_{3}\right)_{6}\right]^{3+}$ and $\left[\mathrm{Ru}\left(\mathrm{NH}_{3}\right)_{6}\right]^{3+}$ of the mononuclear metal-ammine compounds exhibited the highest affinity to heparin, although the $\mathrm{IC}_{50}$ values were significantly higher than that for TriplatinNC (Table 1 and Figure S5). The efficacy of inhibition is charge-dependent, and the $2+$ compounds $\left[\mathrm{Pt}\left(\mathrm{NH}_{3}\right)_{4}\right]^{2+},\left[\mathrm{RuCl}\left(\mathrm{NH}_{3}\right)_{5}\right]^{2+}$, and $\left[\mathrm{CoCl}\left(\mathrm{NH}_{3}\right)_{5}\right]^{2+}$ required over 10-fold more compound for inhibition than $\left[\mathrm{Co}\left(\mathrm{NH}_{3}\right)_{6}\right]^{3+}$ with increasing $\mathrm{IC}_{50}$ (Table 1). Similar trends were observed for TAMRA-R assay (Table 1 and Figure S2c).

ITC Assay. The ITC titrations of metal-ammine species to heparin did not give well-defined isotherms, perhaps because of the inherently lower affinity as measured by the MB reporter assay, and were not analyzed in detail. Affinity values derived from ITC can also vary depending on the nature of the heparin as noted above. ${ }^{45}$

DNA Competition Assays. Metal-ion interactions with nucleic acids have been widely studied; ${ }^{49}$ more specifically, the chosen cobalt and ruthenium complexes bind tightly to DNA. $^{50-54}$ Thus, we compared the affinities of metal-ammine compounds for DNA and heparin. Using the fluorescently labeled DNA-Fl, as was previously done, and heparin MW $\sim 3000$ as the competitor, we examined the relative binding affinity of metal-ammines for these two substrates. Overall, the metal-ammine compounds exhibited at least a 2 -fold increase in $\mathrm{EC}_{50}$ for the highest heparin-DNA ratios, with the largest fold increase of 5.1 observed for $\left[\mathrm{Co}\left(\mathrm{NH}_{3}\right)_{6}\right]^{3+}($ Table 2 and Figure 6). Compared to TriplatinNC, the $\mathrm{EC}_{50}$ values of the metal-ammine compounds binding to DNA were higher (TriplatinNC ${ }^{8+}<\left[\mathrm{Co}\left(\mathrm{NH}_{3}\right)_{6}\right]^{3+}<\left[\mathrm{CoCl}\left(\mathrm{NH}_{3}\right)_{5}\right]^{2+}<[\mathrm{Pt}-$ $\left.\left.\left(\mathrm{NH}_{3}\right)_{4}\right]^{2+} \approx\left[\mathrm{RuCl}\left(\mathrm{NH}_{3}\right)_{5}\right]^{2+}\right)$, indicating the expected lower binding affinity to DNA. Upon competition with heparin, the higher fold increase in $\mathrm{EC}_{50}$ is a measure of the higher heparin affinity, independent of the actual concentrations used for each compound to achieve half-maximal DNA binding. In this case, the trend suggests a strong charge effect, with TriplatinNC ${ }^{8+}$ and $\left[\mathrm{Co}\left(\mathrm{NH}_{3}\right)_{6}\right]^{3+}$ showing the highest relative affinities. The (smaller) one to 2-fold changes for the lower-charged species may reflect inherently stronger binding to DNA rather than a diminished heparin affinity, as can be seen in indirect $\mathrm{MB}$ and TAMRA- $\mathrm{R}_{9}$ assays (Table 1 ).

Because previous studies demonstrated $\left[\mathrm{Pt}\left(\mathrm{NH}_{3}\right)_{4}\right]^{2+}$. and $\left[\mathrm{Co}\left(\mathrm{NH}_{3}\right)_{6}\right]^{3+}$-induced DNA conformational change using $\mathrm{CD},{ }^{53,54}$ we employed this method to observe metal-ammine compound binding to DNA and then the effects of the addition of heparin observed by the return of the DNA conformation. The potential covalent metal-ammine compounds (up to a concentration of $500 \mu \mathrm{M}$ ) did not change the DNA conformation at $280 \mathrm{~nm}$, indicating little interaction, even in 
Table 2. Fluorescence Polarization Assays Showing That Heparin Is a Competitor for Metal-Ammine Compound Binding to DNA

\begin{tabular}{|c|c|c|c|c|c|}
\hline & TriplatinNC ${ }^{8+}$ & {$\left[\mathrm{Co}\left(\mathrm{NH}_{3}\right)_{6}\right]^{3+}$} & {$\left[\mathrm{Pt}\left(\mathrm{NH}_{3}\right)_{4}\right]^{2+}$} & {$\left[\mathrm{RuCl}\left(\mathrm{NH}_{3}\right)_{5}\right]^{2+}$} & {$\left[\mathrm{CoCl}\left(\mathrm{NH}_{3}\right)_{5}\right]^{2+}$} \\
\hline \multicolumn{6}{|c|}{ Competitor $\mathrm{EC}_{50}(\mu \mathrm{M})^{a}$} \\
\hline none & 1.9 & 45.5 & 330 & 388 & 293 \\
\hline $0.20 \mu \mathrm{M}$ heparin & 2.1 & 49.7 & 340 & 395 & 234 \\
\hline $2.11 \mu \mathrm{M}$ heparin & 4.0 & 68.2 & 419 & 479 & 281 \\
\hline $21.2 \mu \mathrm{M}$ heparin & 19.6 & 233 & 655 & 697 & 345 \\
\hline \multicolumn{6}{|c|}{ Competitor Fold Change $\mathrm{EC}_{50}{ }^{b}$} \\
\hline $0.20 \mu \mathrm{M}$ heparin & 1.1 & 1.1 & 1.2 & 1.0 & 0.8 \\
\hline $2.11 \mu \mathrm{M}$ heparin & 2.1 & 1.5 & 1.3 & 1.2 & 1.0 \\
\hline $21.2 \mu \mathrm{M}$ heparin & 10.3 & 5.1 & 2.0 & 1.8 & 1.2 \\
\hline
\end{tabular}

${ }^{a} \mathrm{EC}_{50}$ was determined as the concentration of the complex required for half-maximal binding to fluorescently labeled DNA using heparin MW $\sim 3000$ as a competitor. ${ }^{b}$ The fold change $\mathrm{EC}_{50}$ was calculated as $\left(\mathrm{EC}_{50}\right.$ of the sample with a competitor $) /\left(\mathrm{EC}_{50}\right.$ of the sample without a competitor).

Table 3. EtBr Competition Assay for Comparison of MetalAmmine Binding to DNA and Heparin

\begin{tabular}{ll}
\multicolumn{1}{c}{ metal complex } & $\mathrm{EC}_{50}(\mu \mathrm{M})$ \\
TriplatinNC ${ }^{8+}$ & $24.6 \pm 1.4$ \\
{$\left[\mathrm{Pt}\left(\mathrm{NH}_{3}\right)_{4}\right]^{2+}$} & $<100$ \\
{$\left[\mathrm{Co}\left(\mathrm{NH}_{3}\right)_{6}\right]^{3+}$} & $689 \pm 17$ \\
{$\left[\mathrm{Ru}\left(\mathrm{NH}_{3}\right)_{6}\right]^{3+}$} & $853 \pm 186$ \\
{$\left[\mathrm{RuCl}\left(\mathrm{NH}_{3}\right)_{5}\right]^{2+}$} & $>1000$ \\
{$\left[\mathrm{CoCl}\left(\mathrm{NH}_{3}\right)_{5}\right]^{2+}$} & $>1000$
\end{tabular}

${ }^{a} \mathrm{EC}_{50}$ is defined as the sequestration concentration of heparin MW $\sim 18000$ required to return $50 \% \mathrm{EtBr}$ binding to DNA from the bound metal-ammine compound. $\mathrm{EtBr}$ bound to DNA was normalized to $100 \%$, with EtBr only as $0 \%$.

comparison to the square-planar $\left[\mathrm{Pt}\left(\mathrm{NH}_{3}\right)_{4}\right]^{2+}$ (data not shown).

For EtBr competition assay, at a concentration identical with that of the intercalator, a much larger concentration of $500 \mu \mathrm{M}$ was needed for the mononuclear metal-ammine compounds to displace the EtBr compared to TriplatinNC (12.5 $\mu \mathrm{M}$; Table 3 and Figure S6). Care must be taken in analyzing these trends across a range of compounds because the inherent affinities of the compounds themselves for DNA as a starting point differ widely. Further, the different assays themselves represent different phenomena. The dangers in extrapolating across a series such as the one studied here is demonstrated for $\left[\mathrm{Pt}\left(\mathrm{NH}_{3}\right)_{4}\right]^{2+}$, which has demonstrably low affinity for DNA. ${ }^{55}$ In principle, charge effects $(2+)$ should be the same as those for the $\left[\mathrm{CoCl}\left(\mathrm{NH}_{3}\right)_{5}\right]^{2+}$ and $\left[\mathrm{RuCl}\left(\mathrm{NH}_{3}\right)_{5}\right]^{2+}$ compounds, as seen in fluorescence polarization assay (Table 2 and Figure 6). An apparently higher affinity for heparin in $\mathrm{EtBr}$ assay compared to fluorescence polarization assay may reflect its reduced ability to displace the intercalator, perhaps because of its smaller squareplanar geometry versus the octahedral geometry of the cobalt and ruthenium systems, giving an apparently (but false) higher heparin affinity. This anomaly emphasizes the need to employ more than one approach to assess accurately the questions of relative affinity of heparin and DNA for coordination compounds.

Summary. We observed broadly similar trends for metalammine compound interaction with heparin across the dye reporter techniques and DNA comparison assays. Slight discrepancies can be accounted for by the nature of the technique. Another caveat is the complexity across the experiments where the ITC system is a simple two-species system, heparin-dye reporter assays are three-species system, and DNA comparison assays are four-species systems. Given these caveats, these results are a testament to the relative accuracy of these methods for determining trends of coordination compound interaction with heparin.

\section{CONCLUSIONS}

Overall, oligosaccharide interactions with metal-based compounds are understudied in bioinorganic chemistry. Molecular crowding in the interior of the cell breeds an environment in which molecules must compete with each other, ${ }^{56}$ and small molecules such as cisplatin may encounter many possible binding partners, affecting biodistribution and metabolism, a reflection perhaps of the accepted fact that such a small fraction $(<5 \%)$ of administered drug is considered to bind to its DNA target. $^{24}$ The overall results discussed here suggest comparable affinities for heparin relative to DNA for charged substitutioninert coordination compounds, regardless of their intrinsic nucleic acid affinity. This comparison should be capable of extrapolation to glycosoaminoglycans such as HS. The presence of HS on the cell surface and its relatively similar affinity to DNA would suggest that glycan binding is thus a competitive cellular event for many coordination compounds. ${ }^{21}$ These results extend our understanding of the importance of the interactions of physiologically relevant aquated metal cations with heparin to defined coordination compounds. The available coordinating moieties on HS-heparin are the oxygen-donor atoms of the hard carboxylate and sulfate bases. New patterns of metal-ion binding can be achieved by the interplay and application of hard-soft acid-base concepts. Further, in considering the concept of metalloglycomics, a phrase first coined by Codd, ${ }^{57}$ coordination compounds can be manipulated to modify the oxidation state, ligand lability, and coordination number and geometry to produce a diverse inorganic library.

\section{EXPERIMENTAL SECTION}

Materials. Heparin sodium salts from porcine intestinal mucosa of MW 3000 and 18000, pentaamminechlorocobalt(III) chloride, hexaammineruthenium(III) chloride, and hexaamminecobalt(III) chloride were purchased from Sigma-Aldrich (USA). Pentaamminechlororuthenium(III) chloride was purchased from Aithace Chemical Corp. (USA). TAMRA- $\mathrm{R}_{9}$ and methylene blue chloride were purchased from Anaspec (USA) and Fisher Scientific (USA), respectively. TriplatinNC and tetraammineplatinum(II) chloride were synthesized according to published methods from refs 58 and 59, respectively. The concentrations of heparin were calculated using the dimer IdoA(2S)-GlcNS(6S) with a molecular weight of $609.46 \mathrm{~g} / \mathrm{mol}$ unless otherwise noted. 

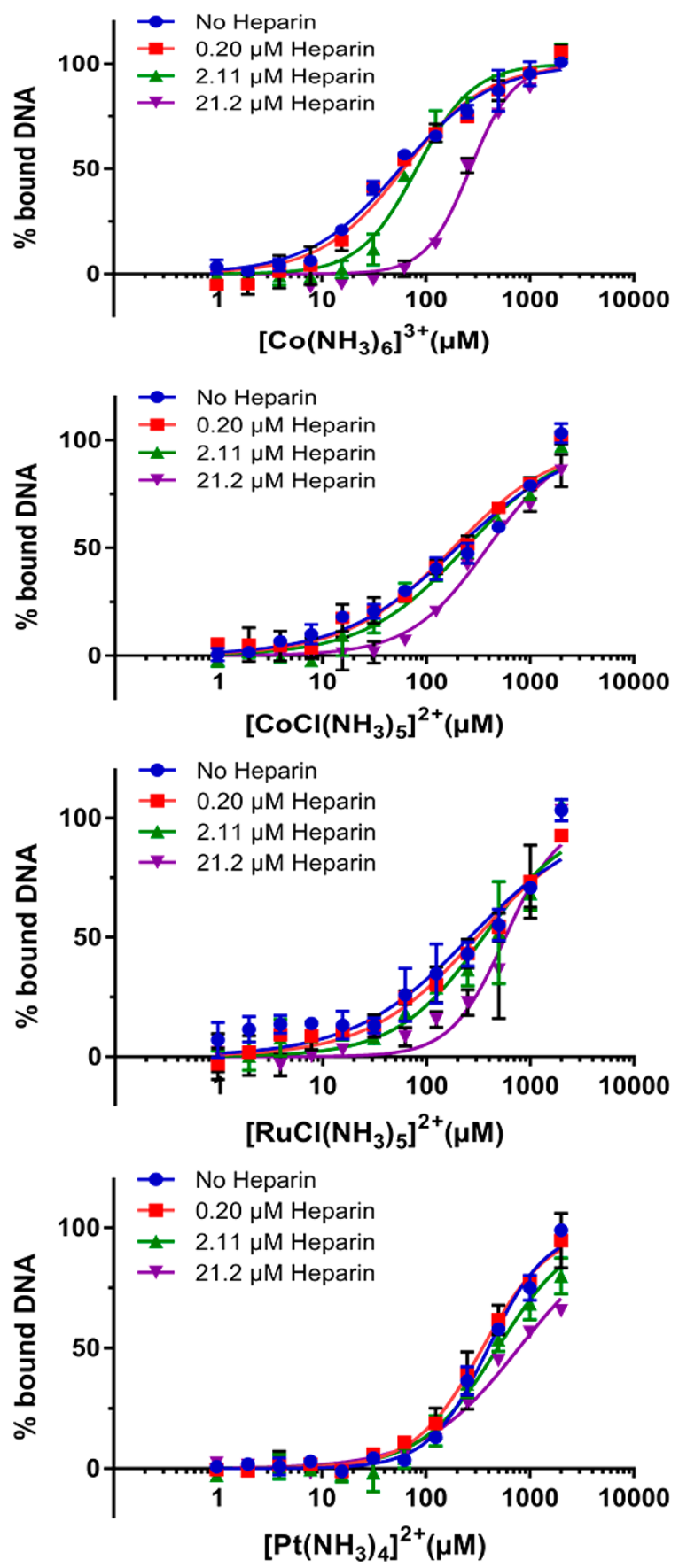

Figure 6. Heparin, a competitor for DNA binding to metal-ammine compounds. The binding of metal-ammine compounds to fluorescently labeled DNA is reduced upon the addition of MW $\sim 3000$ heparin $(0-21.2 \mu \mathrm{M})$.

MB Binding Assay. All heparin-MB binding studies were performed in triplicate on an Agilent 8453 diode-array spectrophotometer in a submicrometer quartz cuvette with a path length of 10 $\mathrm{mm}$. Aqueous solutions of methylene blue chloride (at a constant final concentration of $18.6 \mu \mathrm{M})$ and heparin $\mathrm{MW} 18000(1-25 \mu \mathrm{M})$ were prepared for determination of the optimal heparin-MB binding. A final concentration of $15 \mu \mathrm{M}$ heparin was used for evaluating the inhibition of $\mathrm{MB}$ binding by TriplatinNC $(1-5 \mu \mathrm{M})$, whereas the metal-ammine compounds were studied at the higher $1 \mu \mathrm{M}$ to 1.75 $\mathrm{mM}$ range. The heparin and metal complexes were incubated at room temperature for $15 \mathrm{~min}$ before the addition of methylene blue chloride. Aqueous solutions of methylene blue chloride (at a constant final concentration of $18.6 \mu \mathrm{M}$ ), heparin (MW 18000; at a constant final concentration of $15 \mu \mathrm{M}$ ), and TriplatinNC (at a constant final concentration of $5 \mu \mathrm{M}$ ) were used to evaluate the inhibition of TriplatinNC-heparin binding by physiological relevant concentrations of cations (sodium chloride, 50, 100, and $150 \mathrm{mM}$; potassium chloride, $5 \mathrm{mM}$; calcium chloride, $1.3 \mathrm{mM}$; magnesium chloride, $1 \mathrm{mM}$ ).

TAMRA- $\mathbf{R}_{\mathbf{9}}$ Binding Assay. All heparin-TAMRA- $\mathrm{R}_{\mathbf{9}}$ binding studies were carried out in triplicate. Solutions of TAMRA- $\mathrm{R}_{9}(100$ $\mathrm{nM})$ and heparin $18000 \mathrm{MW}(3 \mu \mathrm{M}$ to $10 \mathrm{mM})$ in cacodylate buffer (200 $\mathrm{mM}, \mathrm{pH}$ 7.4) were prepared to determine the heparin concentration for optimal fluorescence. Heparin $(625 \mu \mathrm{M})$ and metal-ammine compounds (in the range $7.8 \mu \mathrm{M}$ to $2.5 \mathrm{mM}$ ) were incubated for $15 \mathrm{~min}$ at room temperature for compound-heparin binding before the addition of TAMRA- $\mathrm{R}_{9}(100 \mathrm{nM})$ and measurement of the fluorescence.

SPR. Binding experiments were carried out at $25{ }^{\circ} \mathrm{C}$ on a Reichert Technologies (Depew, NY) SR7500DC two-channel system equipped with a Neutravidin-coated mSAM sensor chip (Reichert Technologies, part 13306065) using $10 \mathrm{mM}$ 4-(2-hydroxyethyl)-1-piperazineethanesulfonic acid (HEPES), $150 \mathrm{mM} \mathrm{NaCl}$, and $0.005 \%$ Tween-20 (HBST) as the running buffer. Prior to heparin capture, the Neutravidin-coated mSAM sensor chip was preconditioned with three consecutive injections of $50 \mathrm{mM} \mathrm{NaOH}$ for $1 \mathrm{~min}$, respectively. Biotinylated heparin (MW 15000, Sigma) at a concentration of 100 $\mu \mathrm{g} / \mathrm{mL}$ was subsequently injected onto the avidin surface on the left channel and captured to a level of $110 \mu \mathrm{RIU}(\sim 110 \mathrm{RU})$, whereas the right channel was left as the bare avidin surface to serve as a reference for nonspecific binding of TriplatinNC. Under a flow rate of $25 \mu \mathrm{L} /$ min, TriplatinNC was injected over both channels at concentrations of $5,1,0.33$, and $0.11 \mathrm{mM}$, respectively, for $2 \mathrm{~min}$ followed by a $5 \mathrm{~min}$ dissociation in a HBST running buffer. The kinetic data were analyzed using TraceDrawer (Ridgeview Instruments) with a 1:1 model, while the equilibrium data were fit using Scrubber (Biologic Software) to a 1:1 binding model.

ITC. Calorimetric data were collected using a VP-ITC microcalorimeter (MicroCal, LLC). All samples were degassed for $5 \mathrm{~min}$ using a ThermoVac (MicroCal, LLC). For all titrations, injections of TriplatinNC and metal-ammine compounds $(0.546$ and $4 \mathrm{mM}$, respectively) were pipetted automatically into the reaction cell containing $1.3 \mathrm{~mL}$ of heparin MW $3000(0.1$ and $0.4 \mathrm{mM})$ at $300 \mathrm{~s}$ intervals from a $300 \mu \mathrm{L}$ syringe with stirring at $75 \mathrm{rpm}$. In all experiments, a $100 \mathrm{mM}$ cacodylate buffer $(\mathrm{pH} 7.4)$ was used at $25^{\circ} \mathrm{C}$, and the thermal reference cell contained $1.3 \mathrm{~mL}$ of $100 \mathrm{mM}$ cacodylate buffer ( $\mathrm{pH}$ 7.4). Integration of the thermogram peaks was carried out using the software supplied with the calorimeter (Origin 7.0). The heat released was fitted using Origin 7.0 to determine $K_{a}, \Delta H$, and $\Delta S . \Delta G$ was obtained using Gibbs free energy equation.

Fluorescence Polarization. $50 \mu \mathrm{L}$ binding reactions were carried out at room temperature in 96-well, low-binding, black plates (Greiner) using $100 \mathrm{nM}$ to $25 \mu \mathrm{M}$ of each compound in $1.25 \mathrm{mM}$ $\mathrm{NaCl}, 0.125 \mathrm{mM}$ HEPES ( $\mathrm{pH} 7.2$ ), and $1 \mu \mathrm{M} 3^{\prime}$ fluorescein-labeled hairpin DNA (GGGGCGACTGGTGAGTACGCCCC; $\mathrm{MW}=7705$; Sigma). Readings were recorded immediately after mixing (for no competitor readings). Subsequently, $1 \mu \mathrm{L}$ of $10 \mu \mathrm{M}$ heparin ( $\mathrm{MW}=$ approximately 3000; Sigma) was titrated into each reaction. Readings were recorded immediately. This was followed by titrations of $1 \mu \mathrm{L}$ of $100 \mu \mathrm{M}$ heparin and then $1 \mu \mathrm{L}$ of $1 \mathrm{mM}$ heparin, with immediate readings after each addition. The $\mathrm{EC}_{50}$ calculation was based on the average of three separate experiments.

Ethidium Bromide (EtBr) Displacement Assay with Heparin. Calf-thymus DNA (ct-DNA) was dissolved and dialyzed in HEPES buffer ( $80 \mathrm{mM}$ HEPES, pH 7.2). Buffer exchanges occurred three times every $12 \mathrm{~h}$. The DNA concentration was determined by UV-vis with absorbance at $260 \mathrm{~nm}$ and the average molecular weight of a nucleotide $(333 \mathrm{~g} / \mathrm{mol})$. EtBr at $5 \mathrm{mM}$ in water was diluted in HEPES buffer and incubated with ct-DNA in HEPES buffer for $5 \mathrm{~min}$ at room temperature. An aliquot of $1 \mathrm{mM}$ TriplatinNC ( $4 \mathrm{mM}$ for other compounds) in water was diluted in HEPES buffer and incubated for 1 $\mathrm{h}$ to reduce fluorescence to approximately $30 \%$ (20-25\% for other compounds). Finally, increasing concentrations of heparin MW 18000 in buffer from 20.5 to $82 \mu \mathrm{M}$ final $(100-1000 \mu \mathrm{M}$ final for other 
compounds) were incubated for an additional $1 \mathrm{~h}$. Final concentrations were the following: $\mathrm{EtBr}, 12.5 \mu \mathrm{M}$; ct-DNA, $10 \mu \mathrm{M}$; TriplatinNC, $12.5 \mu \mathrm{M}$ (500 $\mu \mathrm{M}$ for other compounds). All samples were read (after a total of $2 \mathrm{~h} 5 \mathrm{~min}$ ) in a 96-well plate at $530 / 590 \mathrm{~nm}$ using a microplate reader (Bio-Tek instruments). Samples were normalized to the controls ( $\mathrm{EtBr}$ only as $0 \%$ and $\mathrm{EtBr}-\mathrm{DNA}$ as $100 \%)$. All incubations were done at $37{ }^{\circ} \mathrm{C}$.

CD Studies. TriplatinNC ( $r_{\mathrm{i}}=0.075$ compound/DNA ratio) or metal-ammine compounds $\left(r_{\mathrm{i}}=5\right)$ were incubated with $100 \mu \mathrm{M}$ ctDNA for $1 \mathrm{~h}$ at $37^{\circ} \mathrm{C}$ in HEPES buffer ( $80 \mathrm{mM}$ HEPES, pH 7.2). Then heparin MW $\sim 18000$ was added with $10.25-230 \mu \mathrm{M}$ final concentrations (only 10.25-82 $\mu \mathrm{M}$ are shown) and incubated for an additional $1 \mathrm{~h}$ at $37^{\circ} \mathrm{C}$. Final concentrations after heparin addition were the following: $100 \mu \mathrm{M}$ ct-DNA and $7.5 \mu \mathrm{M}$ TriplatinNC $\left(r_{\mathrm{i}}=\right.$ $0.075)$ or $500 \mu \mathrm{M}\left(r_{\mathrm{i}}=5\right)$. After the incubations, samples were placed in a $10 \mathrm{~mm}$ submicro cuvette to record the $\mathrm{CD}$ spectra at room temperature using a Jasco J600 spectropolarimeter.

\section{ASSOCIATED CONTENT}

\section{S Supporting Information}

The Supporting Information is available free of charge on the ACS Publications website at DOI: 10.1021/acs.inorgchem.7b03043.

Calculated $\mathrm{EC}_{50}$ values of TriplatinNC bound to fluorescently labeled DNA competing with unlabeled DNA, TAMRA- $\mathrm{R}_{9}$ inhibition studies, ITC plot of TriplatinNC-heparin binding, CD spectra of DNA comparison assays, graphs of metal-ammine compounds in $\mathrm{MB}$ and $\mathrm{EtBr}$ reporter assays, and $K_{\mathrm{d}}$ calculations of metal-ammine compounds binding to heparin (PDF)

\section{AUTHOR INFORMATION}

\section{Corresponding Author}

*E-mail: npfarrell@vcu.edu.

\section{ORCID $\odot$}

Nicholas P. Farrell: 0000-0001-7160-7182

Notes

The authors declare no competing financial interest.

\section{ACKNOWLEDGMENTS}

The authors gratefully acknowledge Eric Ginsburg for synthesizing tetraammineplatinum(II) chloride and Daniel Lee for synthesizing TriplatinNC. This research was supported, in part, by Grant NIH RO1CA78754. This project has been partly supported by pilot funding from the Massey Cancer Center, VCU, with funding, in part, from NIH-NCI Cancer Center Support Grant P30 CA016059.

\section{REFERENCES}

(1) Varki, A.; Cummings, R. D.; Esko, J. D.; Freeze, H. H.; Stanley, P.; Bertozzi, C. R.; Hart, G. W.; Etzler, M. E. Essentials of Glycobiology, 2nd ed.; Cold Spring Harbor Laboratory Press: Cold Spring Harbor, NY, 2009.

(2) Cummings, R. D.; Pierce, J. M. The Challenge and Promise of Glycomics. Chem. Biol. 2014, 21, 1-15.

(3) Capila, I.; Linhardt, R. J. Heparin - Protein Interactions. Angew. Chem., Int. Ed. 2002, 41, 390-412.

(4) Humphries, D. E.; Wong, G. W.; Friend, D. S.; Gurish, M. F.; Qiu, W. T.; Huang, C.; Sharpe, A. H.; Stevens, R. L. Heparin is essential for the storage of specific granule proteases in mast cells. Nature 1999, 400, 769-772.

(5) Meneghetti, M. C. Z.; Hughes, A. J.; Rudd, T. R.; Nader, H. B.; Powell, A. K.; Yates, E. A.; Lima, M. A. Heparan sulfate and heparin interactions with proteins. J. R. Soc., Interface 2015, 12, 20150589.
(6) Chiodelli, P.; Bugatti, A.; Urbinati, C.; Rusnati, M. Heparin/ heparan sulfate proteoglycans glycomic interactome in angiogenesis: Biological implications and therapeutical use. Molecules 2015, 20, 6342-6388.

(7) Xu, D.; Esko, J. D. Demystifying heparan sulfate-protein interactions. Annu. Rev. Biochem. 2014, 83, 129-57.

(8) Hudak, J. E.; Bertozzi, C. R. Glycotherapy: New advances inspire a reemergence of glycans in medicine. Chem. Biol. 2014, 21, 16-37.

(9) Jia, L.; Ma, S. Recent advances in the discovery of heparanase inhibitors as anti-cancer agents. Eur. J. Med. Chem. 2016, 121, 209220.

(10) Vlodavsky, I.; Friedmann, Y.; Elkin, M.; Aingorn, H.; Atzmon, R.; Ishai-Michaeli, R.; Bitan, M.; Pappo, O.; Peretz, T.; Michal, I.; Spector, L.; Pecker, I. Mammalian heparanase: gene cloning, expression and function in tumor progression and metastasis. Nat. Med. 1999, 5, 793-802.

(11) Baraz, L.; Haupt, Y.; Elkin, M.; Peretz, T.; Vlodavsky, I. Tumor suppressor p53 regulates heparanase gene expression. Oncogene 2006, $25,3939-3947$.

(12) Pisano, C.; Vlodavsky, I.; Ilan, N.; Zunino, F. The potential of heparanase as a therapeutic target in cancer. Biochem. Pharmacol. 2014, $89,12-19$.

(13) Zhang, F.; Liang, X.; Beaudet, J. M.; Lee, Y.; Linhardt, R. J. The effects of metal ions on heparin/heparin sulfate-protein interactions. J. Biom. Technol. Res. 2014, 1, 6000101.

(14) Seo, Y.; Schenauer, M. R; Leary, J. A. Biologically Relevant Metal-Cation Binding Induces Conformational Changes in Heparin Oligosaccharides as Measured by Ion Mobility Mass Spectrometry. Int. J. Mass Spectrom. 2011, 303, 191-198.

(15) Stevic, I.; Parmar, N.; Paredes, N.; Berry, L. R.; Chan, A. K. C. Binding of Heparin to Metals. Cell Biochem. Biophys. 2011, 59, 171178.

(16) Shao, C.; Zhang, F.; Kemp, M. M.; Linhardt, R. J.; Waisman, D. M.; Head, J. F.; Seaton, B. A. Crystallographic Analysis of Calciumdependent Heparin Binding to Annexin A2. J. Biol. Chem. 2006, 281, 31689-31695.

(17) Xie, H.; Kang, Y. J. Role of copper in angiogenesis and its medicinal implications. Curr. Med. Chem. 2009, 16, 1304-1314.

(18) D’Andrea, L. D.; Romanelli, A.; Di Stasi, R.; Pedone, C. Bioinorganic aspects of angiogenesis. Dalt. Trans. 2010, 39, 76257636.

(19) Rudd, T. R.; Skidmore, M. A.; Guimond, S. E.; Guerrini, M.; Cosentino, C.; Edge, R.; Brown, A.; Clarke, D. T.; Torri, G.; Turnbull, J. E.; Nichols, R. J.; Fernig, D. G.; Yates, E. A. Site-specific interactions of copper(II) ions with heparin revealed with complementary (SRCD, NMR, FTIR and EPR) spectroscopic techniques. Carbohydr. Res. 2008, 343, 2184-2193.

(20) Hung, K.-W.; Kumar, T. K. S.; Kathir, K. M.; Xu, P.; Ni, F.; Ji, H.-H.; Chen, M.-C.; Yang, C.-C.; Lin, F.-P.; Chiu, I.-M.; Yu, C. Solution Structure of the Ligand Binding Domain of the Fibroblast Growth Factor Receptor: Role of Heparin in the Activation of the Receptor. Biochemistry 2005, 44, 15787-15798.

(21) Silva, H.; Frézard, F.; Peterson, E. J.; Kabolizadeh, P.; Ryan, J. J.; Farrell, N. P. Heparan sulfate proteoglycan-mediated entry pathway for charged tri-platinum compounds. Differential cellular accumulation mechanisms for platinum. Mol. Pharmaceutics 2012, 9, 1795-1802.

(22) Peterson, E. J.; Daniel, A. G.; Katner, S. J.; Bohlmann, L.; Chang, C.-W.; Bezos, A.; Parish, C. R.; von Itzstein, M.; Berners-Price, S. J.; Farrell, N. P. Antiangiogenic platinum through glycan targeting. Chem. Sci. 2017, 8, 241-252.

(23) Mangrum, J. B.; Engelmann, B. J.; Peterson, E. J.; Ryan, J. J.; Berners-Price, S. J.; Farrell, N. P. A new approach to glycan targeting: enzyme inhibition by oligosaccharide metalloshielding. Chem. Commun. (Cambridge, U. K.) 2014, 50, 4056-4058.

(24) Farrell, N. P. Multi-platinum anti-cancer agents. Substitutioninert compounds for tumor selectivity and new targets. Chem. Soc. Rev. 2015, 44, 8773-8785.

(25) Katner, S. J.; Petson, E. J.; Katsuta, E.; DeMasi, S. C.; Koblinski, J.; Takabe, K.; Farrell, N. P. Anti-metastatic platinum through glycan 
targeting in breast cancer. Proceedings of the AACR, Washington, DC, 2017; Abstract 17.

(26) Katsuta, E.; Peterson, E. J.; Katner, S. J.; Farrell, N. P.; Takabe, $\mathrm{K}$. Triplatin preferably suppress lung metastasis of breast cancer, and peritoneal carcinomatosis of colon and pancreatic cancer. Proceedings of the AACR, Washington, DC, 2017; Abstract 5117.

(27) Waller, L. N.; Fox, N.; Fox, K. F.; Fox, A.; Price, R. L. Ruthenium red staining for ultrastructural visualization of a glycoprotein layer surrounding the spore of Bacillus anthracis and Bacillus subtilis. J. Microbiol. Methods 2004, 58, 23-30.

(28) Rozenberg, G. I.; Espada, J.; de Cidre, L. L.; Eijan, A. M.; Calvo, J. C.; Bertolesi, G. E. Heparan sulfate, heparin, and heparinase activity detection on polyacrylamide gel electrophoresis using the fluorochrome tris (2,2'-bipyridine)ruthenium(II). Electrophoresis 2001, 22, $3-11$.

(29) Cheng, T.-T.; Yao, J.-L.; Gao, X.; Sun, W.; Shi, S.; Yao, T.-M. A new fluorescence 'switch on' assay for heparin detection by using a functional ruthenium polypyridyl complex. Analyst 2013, 138, 34833489.

(30) Jiao, Q. C.; Liu, Q.; Sun, C.; He, H. Investigation on the binding site in heparin by spectrophotometry. Talanta 1999, 48, 1095-1101.

(31) Tan, L.; Yao, S.; Xie, Q. Electrochemical determination of heparin using methylene blue probe and study on competition of $\mathrm{Ba}^{2+}$ with methylene blue for binding heparin. Talanta 2007, 71, 827-832.

(32) Chu, H.; Johnson, N. R.; Mason, N. S.; Wang, Y. A [polycation:heparin] complex releases growth factors with enhanced bioactivity. J. Controlled Release 2011, 150, 157-163.

(33) Zhang, L.; Li, N.; Zhao, F.; Li, K. Spectroscopic study on the interaction between methylene blue and chondroitin 4-sulfate and its analytical application. Anal. Sci. 2004, 20, 445-50.

(34) Hibino, K.; Yoshikawa, Y.; Murata, S.; Saito, T.; Zinchenko, A. A.; Yoshikawa, K. Na+ more strongly inhibits DNA compaction by spermidine (3+) than K+. Chem. Phys. Lett. 2006, 426, 405-409.

(35) Malina, J.; Farrell, N. P.; Brabec, V. Substitution-inert trinuclear platinum complexes efficiently condense/aggregate nucleic acids and inhibit enzymatic activity. Angew. Chem., Int. Ed. 2014, 53, 1281212816.

(36) Malina, J.; Farrell, N. P.; Brabec, V. DNA condensing effects and sequence selectivity of DNA binding of antitumor noncovalent polynuclear platinum complexes. Inorg. Chem. 2014, 53, 1662-1671.

(37) Fuchs, S. M.; Raines, R. T. Pathway for Polyarginine Entry into Mammalian Cells. Biochemistry 2004, 43, 2438-2444.

(38) Du, X.; Li, Y.; Xia, Y.-L.; Ai, S.-M.; Liang, J.; Sang, P.; Ji, X.-L.; Liu, S.-Q. Insights into Protein-Ligand Interactions: Mechanisms, Models, and Methods. Int. J. Mol. Sci. 2016, 17, 144.

(39) Gaus, K.; Hall, E. A. H. Surface Modification Method for Adhesion of Gels. J. Colloid Interface Sci. 1997, 194, 373-378.

(40) Osmond, R. I. W.; Kett, W. C.; Skett, S. E.; Coombe, D. R. Protein-heparin interactions measured by BIAcore 2000 are affected by the method of heparin immobilization. Anal. Biochem. 2002, 310, 199-207.

(41) Cochran, S.; Li, C. P.; Ferro, V. A surface plasmon resonancebased solution affinity assay for heparan sulfate-binding proteins. Glycoconjugate J. 2009, 26, 577-587.

(42) Leavitt, S.; Freire, E. Direct measurement of protein binding energetics by isothermal titration calorimetry. Curr. Opin. Struct. Biol. 2001, 11, 560-566.

(43) Dutta, A. K.; Rosgen, J.; Rajarathnam, K. Using Isothermal Titration Calorimetry to Determine Thermodynamic Parameters of Protein-Glycosaminoglycan Interactions. Methods Mol. Biol. 2015, 1229, 315-324.

(44) Pantoliano, M. W.; Horlick, R. A.; Springer, B. A.; Van Dyk, D. E.; Tobery, T.; Wetmore, D. R.; Lear, J. D.; Nahapetian, A. T.; Bradley, J. D.; Sisk, W. P. Multivalent ligand-receptor binding interactions in the fibroblast growth factor system produce a cooperative growth factor and heparin mechanism for receptor dimerization. Biochemistry 1994, 33, 10229-10248.

(45) Brown, A.; Robinson, C. J.; Gallagher, J. T.; Blundell, T. L. Cooperative heparin-mediated oligomerization of fibroblast growth factor-1 (FGF1) precedes recruitment of FGFR2 to ternary complexes. Biophys. J. 2013, 104, 1720-1730.

(46) Brown, A. Analysis of Cooperativity by Isothermal Titration Calorimetry. Int. J. Mol. Sci. 2009, 10, 3457-3477.

(47) Powell, A. K.; Yates, E. A.; Fernig, D. G.; Turnbull, J. E. Interactions of heparin/heparan sulfate with proteins: Appraisal of structural factors and experimental approaches. Glycobiology 2004, 14, 17R-30R.

(48) Prisecaru, A.; Molphy, Z.; Kipping, R. G.; Peterson, E. J.; Qu, Y.; Kellett, A.; Farrell, N. P. The phosphate clamp: Sequence selective nucleic acid binding profiles and conformational induction of endonuclease inhibition by cationic Triplatin complexes. Nucleic Acids Res. 2014, 42, 13474-13487.

(49) Biver, T. Stabilisation of non-canonical structures of nucleic acids by metal ions and small molecules. Coord. Chem. Rev. 2013, 257, $2765-2783$.

(50) Bharanidharan, D.; Thiyagarajan, S.; Gautham, N. Hexammineruthenium(III) ion interactions with Z-DNA. Acta Crystallogr., Sect. F: Struct. Biol. Cryst. Commun. 2007, 63, 1008-1013. (51) Tselepi-Kalouli, E.; Katsaros, N. The Interaction of $[\mathrm{Ru}-$ $\left.\left(\mathrm{NH}_{3}\right)_{5} \mathrm{Cl}\right]^{2+}$ and $\left[\mathrm{Ru}\left(\mathrm{NH}_{3}\right)_{6}\right]^{3+}$ Ions with DNA. J. Inorg. Biochem. 1989, 37, 271-282.

(52) Matulis, D.; Rouzina, I.; Bloomfield, V. A. Thermodynamics of DNA binding and condensation: isothermal titration calorimetry and electrostatic mechanism. J. Mol. Biol. 2000, 296, 1053-1063.

(53) Deng, H.; Bloomfield, V. A. Structural effects of cobalt-amine compounds on DNA condensation. Biophys. J. 1999, 77, 1556-1561.

(54) Kankia, B. I.; Buckin, V.; Bloomfield, V. A. Hexamminecobalt(III)-induced condensation of calf thymus DNA: circular dichroism and hydration measurements. Nucleic Acids Res. 2001, 29, 2795-2801.

(55) Carte, N.; Legendre, F.; Leize, E.; Potier, N.; Reeder, F.; Chottard, J.-C.; Van Dorsselaer, A. Determination by electrospray mass spectrometry of the outersphere association constants of DNA/ platinum complexes using 20-mer oligonucleotides and ([Pt$\left.\left.\left(\mathrm{NH}_{3}\right)_{4}\right]^{2+}, 2 \mathrm{C}^{-}\right)$or $\left(\left[\mathrm{Pt}(\mathrm{py})_{4}\right]^{2+}, 2 \mathrm{Cl}^{-}\right)$. Anal. Biochem. 2000, 284, 77-86.

(56) McGuffee, S. R.; Elcock, A. H. Diffusion, Crowding \& Protein Stability in a Dynamic Molecular Model of the Bacterial Cytoplasm. PLoS Comput. Biol. 2010, 6, e1000694.

(57) Codd, R. Metalloglycomics: a new perspective upon competitive metal-carbohydrate binding using EPR spectroscopy. Chem. Commun. 2004, 2653-2655.

(58) Harris, A. L.; Yang, X.; Hegmans, A.; Povirk, L.; Ryan, J. J.; Kelland, L.; Farrell, N. P. Synthesis, Characterization, and Cytotoxicity of a Novel Highly Charged Trinuclear Platinum Compound. Enhancement of Cellular Uptake with Charge. Inorg. Chem. 2005, 44, 9598-9600.

(59) Kauffman, G. B.; Cowan, D. O. In Inorganic Synthesis; Klienberg, J., Eds.; McGraw-Hill Book Co., Inc.: New York, 1963; Vol. 7, Chapter 63, pp239-245. 